\title{
PENINGKATAN PEMAHAMAN FIGURATIVE LANGUAGE DALAM MATA KULIAH SPEAKING MELALUI TEKNIK DRAMA
}

\author{
Salwa, Ayu Liskinasih \\ Universitas Kanjuruhan Malang, Kota Malang, Jawa Timur \\ Email: salwa@unikama.ac.id
}

\begin{abstract}
This study is aimed at identifying the learning problems faced by students majoring English Education at University of Kanjuruhan Malang. The students had difficulties in understanding the meanings of figurative language particulary when they are used in the literary work. Therefore, the researcher applied a drama project to help students comprehend the meanings of figurative language and also increase their speaking skill as well. This study was a mixed- research applying two phases which were quantitative by using a quasi-experimental design and the second one was a qualitative study by applying a case study and focus group discussion (FGD). The findings of the study showed that the use of a project drama has a significant effect on the figurative language learning process since the score increased from 76,5 to 81,36 and the students also showed positive attitudes towards the use of project drama in the teaching of figurative language.
\end{abstract}

Keywords : Figurative language, speaking, drama.

\begin{abstract}
ABSTRAK: Penelitian ini bertujuan untuk mengidentifikasi permasalahan yang dihadapi mahasiswa jurusan pendidikan Bahasa Inggris Universitas Kanjuruhan Malang dimana penelitian awal menunjukkan bahwasanya para mahasiswa mengalami kesulitan dalam menggunakan ragam majas (figurative language yang tepat serta kesulitan dalam memahami makna-makna majas tersebut, hal tersebut dikarenakan terbatasnya pengajaran kosa kata tentang majas serta penagajaran bahasa yang lebih menekankan pada faktor tata bahasa (grammar) saja. tim peneliti tergerak untuk menerapkan drama project pada mata kuliah speaking sebagai suatu metode untuk peningkatan pemahaman mahasiswa akan penggunaan majas (figurative language) yang nantinya akan diterapkan dalam penulisan naskah drama dan akan ditampilkan didalam kelas oleh tiap-tiap group mahasiswa yang secara tidak langsung juga akan meningkatkan keterampilan berbicara (speaking) dan meningkatkan kepercayaan diri untuk berbicara didepan umum.Penelitian ini menggunakan metode campuran dengan penjelasan berkelanjutan (sequential explanatory) dengan dua fase. Fase pertama merupakan penelitian kuantitatif dengan menggunakan desain quasi-experimental sedangkan fase kedua merupakan penelitian kualitatif dengan desain studi kasus. Hasil dari post-test menunjukkan adanya peningkatan skor kemampuan mahasiswa dari76,5 menjadi 81,36 serta hasil dari Focus Group Discussion (FGD) menunjukkan bahwa para mahasiswa merasa lebih mudah memahami figurative language melalui project drama.
\end{abstract}

Kata-kata kunci : majas, keterampilan berbicara, drama

Selama ini banyak penelitian tentang penggunaan figurative language yang terdapat didalam puisi, lagu, dan karya sastra lain ( Utami, 2012; Retnayanthi, 2013), namun sangat jarang dilakukan penelitian tentang pengajaran figurative language dalam bentuk drama, karena itulah penelitian ini perlu dilakukan mengingat saat ini di Indonesia pengajaran bahasa asing dalam hal ini Bahasa Inggris menggunakan metode Centextual Language Teaching (CLT) dimana pembelajaran bahasa Inggris akan lebih berhasil jika difokuskan pada konteks atau bahasa dan budaya sehari-hari.

Penelitian ini menggunakan teknik drama sebagai strategi pembelajaran figurative language dengan beberapa pertimbangan yaitu drama merupakan salah satu karya sastra yang mempunyai nilai penting dalam pendidikan dikarenakan drama tidak hanya meningkatkan ketermpilan berbahasa tetapi juga dapat 
mengembangkan rasa dan nilai hidup serta membentuk karakter para peserta didik.

Pada penelitian ini para mahasiswa akan menampilkan drama secara live di depan kelas dengan tahapan awal yaitu menulis naskah ( script) yang berisi beberapa figurative language. Hal ini akan secara langsung dapat meningkatkan kemampuan speaking juga rasa percaya diri para mahasiswa

\section{METODE}

Subyek dalam penelitian ini adalah 15 orang mahasiswa semester 4 Program Studi Pendidikan Bahasa Inggris di dua kelas mata kuliah Speaking. Kedua kelas ini sengaja dipilih menurut kesetaraan kemampuan mahasiswa karena pemilihan sampel secara acak dari seluruh populasi tidak mungkin dilakukan. Penelitian ini dilakukan di kelas mata kuliah speaking program studi Pendidikan bahasa Inggris Universitas Kanjuruhan Malang. Penelitian ini menggunakan metode campuran dengan penjelasan berkelanjutan (Sequential Explanatory) dengan dua fase. Fase pertama merupakan penelitian kuantitatif dengan desain quasi-eksperimental. Sedangkan fase kedua merupakan penelitian kualitatif dengan desain studi kasus. Metode penelitian campuran dengan penjelasan berkelanjutan ini dipakai untuk menjelaskan dan mengintepretasikan hasil penelitian kuantitatif melalui pengumpulan dan analisa data kualitatif (Creswell, 2009: 211).

Menurut Latief (2012: 95), desain penelitian quasi-eksperimental digunakan ketika tidak dimungkinkan mengambil sampel secara acak dari populasi, sehingga kelas yang diteliti dalam penelitian ini sengaja dipilih sesuai dengan kesetaraan level mahasiswa. kemudian diberikan treatment yang berbeda, yaitu berupa ceramah dan penggunaan drama project dalam pembelajaran. Pre-test dan posttest digunakan untuk membantu menentukan ada tidaknya hasil setelah dilakukan treatment.

Desain studi kasus pada fase kedua digunakan untuk menindak lanjuti hasil temuan kuantitatif. Studi kasus dipilih karena adanya batasan waktu dan aktifitas (Creswell, 2009:13). Penelitian ini menggunakan instrument soal pre-test dan post-test serta diadakan grup diskusi terfokus yang bertujuan untuk menggali persepsi mahasiswa akan penggunaan drama project di kelas speaking untuk pembelajaran figurative language

.serta untuk mengetahui pendapat mahasiswa akan hasil penelitian kuantitatif di fase pertama.

Prosedur penelitian dalam metode penelitian campuran dengan penjelasan berkelanjutan ini dapat dijabarkan melalui Gambar 3.1.

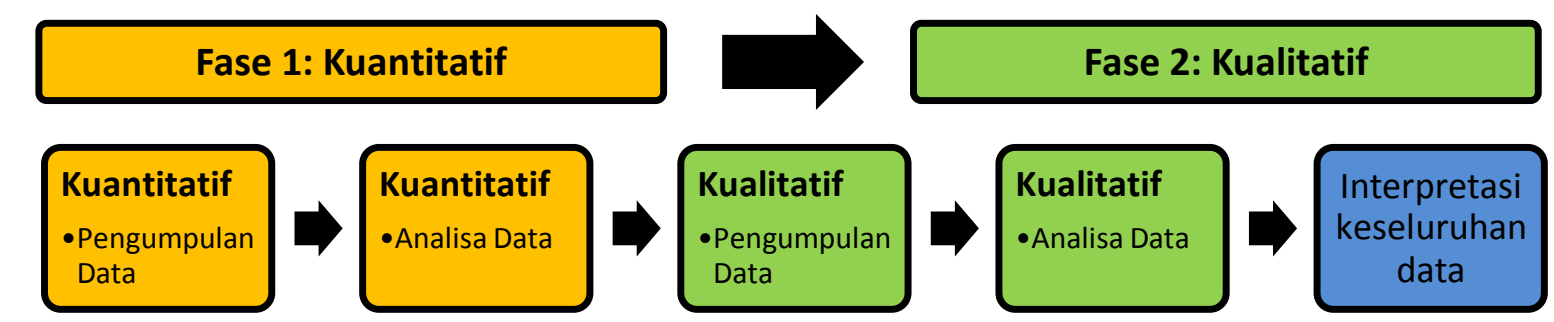

Gambar 3.1. Metode Penelitian Campuran dengan Penjelasan Berkelanjutan (Creswell, 2009: 209)

\section{Analisa Data Kuantitatif}

Nilai Pre-Test dan Post-Test mahasiswa di kedua kelompok dianalisa dengan menggunakan kalkulasi statistik statistik SPSS 22.0 dan uji homogenitas menggunakan statistic One-Way ANCOVA.

\section{Pengumpulan Data Kualitatif}

Simpulan dari hasil kalkulasi statistik fase pertama penelitian menjadi dasar penyusunan panduan pertanyaan untuk grup diskusi terfokus. Selanjutnya peneliti akan membagi mahasiswa-mahasiswa di kelompok ekperimental dalam beberapa kelompok kecil yang terdiri dari 5-6 orang. Secara bergiliran, peneliti akan memandu diskusi terfokus di setiap grup. Diskusi sengaja dilakukan di dalam grup agar mahasiswa merasa lebih nyaman dan tidak segan mengemukakan pendapatnya. Setiap diskusi direkam dengan 
kamera video, alat perekam suara, dan catatan lapangan.

\section{Analisa Data Kualitatif}

Transkrip hasil rekaman kamera video dan alat perekam suara dan catatan lapangan menjadi dasar analisis data. Peneliti akan memilah data yang sesuai dengan rumusan masalah. Data-data ini kemudian dirumuskan dalam beberapa tema yang menjelaskan persepsi mahasiswa akan penggunaan metode drama dalam pembelajaran topik Figurative Language di kelas Speaking.

\section{Interpretasi Keseluruhan Data}

Untuk menjawab rumusan masalah penelitian, interpretasi dari seluruh data yang dikumpulkan perlu dilakukan. Interpretasi dimulai dengan penarikan simpulan dari penelitian kuantitatif yang dikuatkan dengan temuan-temuan pada penelitian kualitatif.

\section{HASIL DAN PEMBAHASAN}

\section{Analisis Data Kuantitatif}

Data nilai pretest dan post-test mahasiswa yang telah dikumpulkan diolah dengan software statistik SPSS 22.0. Hasil pengolahan analisis statistik dapat dijabarkan sebagai berikut:

Tabel 1. Analisis Frekuensi

\begin{tabular}{llllr}
\hline Statistics & & & & \\
\hline $\mathrm{N}$ & & Pretest & \multicolumn{2}{c}{ Posttest } \\
& Valid & 25 & \multicolumn{2}{c}{25} \\
\cline { 2 - 5 } & Missing & 0 & 76.5600 & \\
\hline Mean & & 76.0000 & 81.3600 \\
Median & & $75.00^{\mathrm{a}}$ & 82.0000 \\
Mode & & 3.60648 & 83.00 \\
Std. Deviation & & 13.007 & 3.14749 \\
Variance & & 67.00 & 9.907 \\
Minimum & & 83.00 & 75.00 \\
Maximum & & 1914.00 & 87.00 \\
Sum & & 75.0000 & 2034.00 \\
\hline Percentiles & 25 & & 76.0000 & 78.5000 \\
& 50 & & 80.0000 & 82.0000 \\
& 75 & & 83.5000 \\
\hline
\end{tabular}

${ }^{a}$ Multiple modes exist. The smallest value is shown

Sebaran nilai pada Tabel 1 menunjukkan bahwa terjadi kenaikan baik dari nilai minimum dan nilai maksimum dari pretest ke post-test. Nilai terendah pada pretest yaitu 67 berhasil meningkat menjadi 75 . Demikian pula nilai tertinggi yang diperoleh siswa meningkat dari 83 menjadi 87. Secara singkat, hal ini menunjukkan bahwa rata-rata nilai di kelas (mean) naik dari 76,55 menjadi 81,36 . Nilai tengah(median) yang awalnya 76 menjadi 82 , yang artinya separuh mahasiswa di kelas tersebut memperoleh nilai lebih dari atau sama dengan 82. Sedangkan nilai yang paling banyak muncul/ modus (selengkapnya lihat Tabel 2) menunjukkan hasil yang sangat baik. Jika pada pretest nilai yang paling banyak muncul adalah 75, pada hasil post-test nilai yang paling banyak muncul adalah 83 .
Jika dilihat dari perbedaan nilai varian, pada pretest nilai varian lebih tinggi dibanding posttest, yaitu 13,007. Hal ini dapat diartikan bahwa kemampuan mahasiswa tentang materi figurative language sebelum dilakukan treatment penggunaan teknik drama cukup beragam, banyak yang paham dengan materi, banyak pula yang tidak. Penurunan nilai varian pada hasil post-test menunjukkan tingkat keseragaman pemahaman materi pada mahasiswa. Sehingga dapat disimpulkan, setelah mendapatkan treatment penggunaan teknik drama lebih banyak mahasiswa yang menguasai materi figurative language. 
Tabel 2. Perbandingan Frekuensi Data Pretest \& Post Test

\begin{tabular}{|c|c|c|c|c|c|}
\hline \multicolumn{6}{|c|}{ Pretest } \\
\hline & & Frequency & Percent & Valid Percent & Cumulative Percent \\
\hline \multirow[t]{11}{*}{ Valid } & 67.00 & 1 & 4.0 & 4.0 & 4.0 \\
\hline & 70.00 & 1 & 4.0 & 4.0 & 8.0 \\
\hline & 73.00 & 1 & 4.0 & 4.0 & 12.0 \\
\hline & 74.00 & 2 & 8.0 & 8.0 & 20.0 \\
\hline & 75.00 & 5 & 20.0 & 20.0 & 40.0 \\
\hline & 76.00 & 4 & 16.0 & 16.0 & 56.0 \\
\hline & 78.00 & 4 & 16.0 & 16.0 & 72.0 \\
\hline & 80.00 & 5 & 20.0 & 20.0 & 92.0 \\
\hline & 82.00 & 1 & 4.0 & 4.0 & 96.0 \\
\hline & 83.00 & 1 & 4.0 & 4.0 & 100.0 \\
\hline & Total & 25 & 100.0 & 100.0 & \\
\hline \multicolumn{6}{|c|}{ Posttest } \\
\hline & & Frequency & Percent & Valid Percent & Cumulative Percent \\
\hline \multirow[t]{11}{*}{ Valid } & 75.00 & 1 & 4.0 & 4.0 & 4.0 \\
\hline & 78.00 & 5 & 20.0 & 20.0 & 24.0 \\
\hline & 79.00 & 3 & 12.0 & 12.0 & 36.0 \\
\hline & 80.00 & 3 & 12.0 & 12.0 & 48.0 \\
\hline & 82.00 & 1 & 4.0 & 4.0 & 52.0 \\
\hline & 83.00 & 6 & 24.0 & 24.0 & 76.0 \\
\hline & 84.00 & 2 & 8.0 & 8.0 & 84.0 \\
\hline & 85.00 & 1 & 4.0 & 4.0 & 88.0 \\
\hline & 86.00 & 2 & 8.0 & 8.0 & 96.0 \\
\hline & 87.00 & 1 & 4.0 & 4.0 & 100.0 \\
\hline & Total & 25 & 100.0 & 100.0 & \\
\hline
\end{tabular}

Tabel 2 memperjelas penjabaran modus pada Tabel 1, dimana nilai yang paling banyak muncul pada hasil pretest yaitu 75 (sebanyak 5x) diikuti 80 (sebanyak 5x); sedangkan pada post-test, nilai yang paling banyak muncul yaitu 83 (sebanyak 6x) diikuti 78 (sebanyak $5 x)$. Patut dicatat bahwa pada pretest, hanya ada 1 mahasiswa yang meraih nilai 83 yang juga merupakan nilai tertinggi. Namun pada post-test, setidaknya 12 mahasiswa mendapatkan nilai lebih dari atau sama dengan 83. Hal ini menunjukkan bahwa kenaikan nilai tidak hanya ditandai dengan naiknya nominal nilai tertinggi, tetapi juga jumlah mahasiswa yang mampu mendapatkan nilai tersebut. Sehingga, dapat ditafsirkan bahwa setelah dilakukan treatment penggunaan teknik drama, pemahaman mahasiswa terhadap materi naik signifikan, hingga hampir separuh jumlah mahasiswa mendapatkan skor lebih tinggi dari nilai tertinggi pada pretest. Secara visual, grafik kenaikan nilai mahasiswa pada pretest dan post-test digambarkan pada Gambar 1 dan Gambar 2.
Secara visual, tampak dari perbandingan Gambar 1 dan Gambar 2 bahwa standar deviasi dan varian pada pretest jauh lebih tinggi daripada post-test. Hal ini membuktikan bahwa penggunaan teknik drama yang dilakukan telah berhasil memperkecil kesenjangan pemahaman materi figurative language pada siswa di kelas tersebut.

\section{A. Uji Normalitas}

Uji normalitas perlu dilakukan untuk mengukur apakah data yang telah diperoleh memiliki distribusi normal, sehingga hasil penelitian ini dapat digeneralisasikan pada populasi. Hasil uji normalitas ditunjukkan pada Tabel 3 berikut ini: 


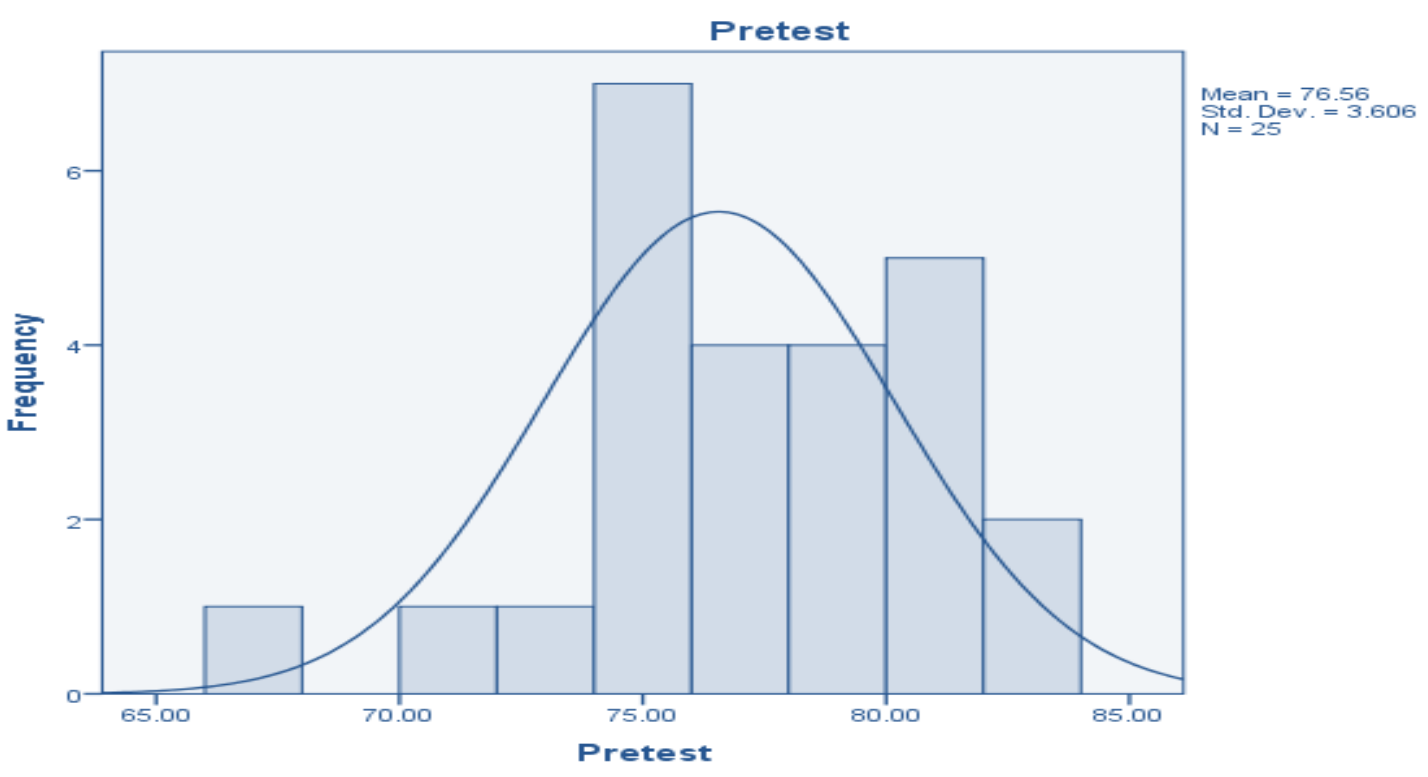

Gambar 1. Grafik Frekuensi Nilai Pretest

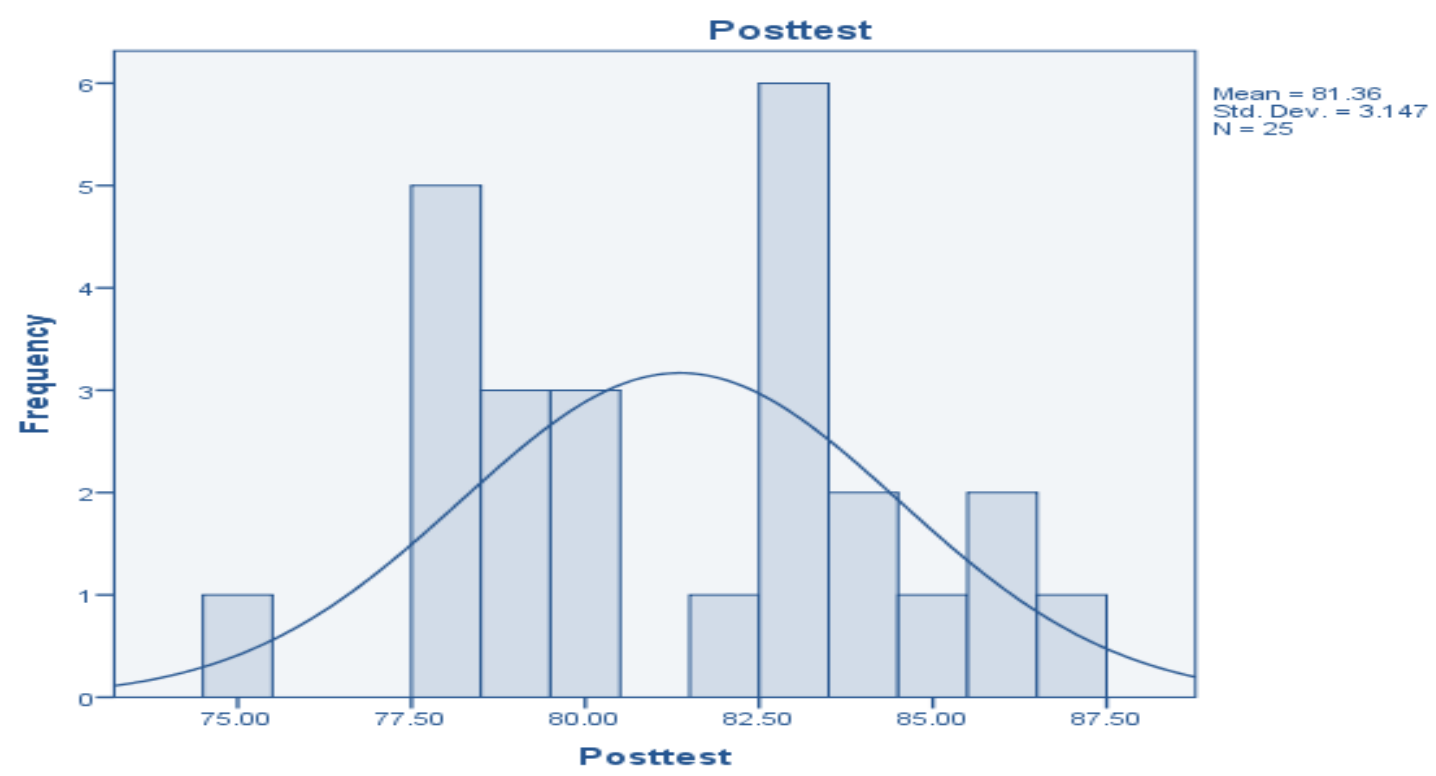

Gambar 2. Grafik Frekuensi Nilai Post-Test

Tabel 3. Hasil Uji Normalitas

\begin{tabular}{lcccccc}
\hline \multicolumn{9}{c}{ Tests of Normality $^{\text {Kolmogorov-Smirnov }}{ }^{\mathrm{a}}$} & \multicolumn{3}{c}{ Shapiro-Wilk } \\
\cline { 2 - 8 } & Statistic & df & Sig. & Statistic & df & Sig. \\
\hline Pretest & .133 & 25 & $.200^{*}$ & .948 & 25 & .230 \\
Posttest & .179 & 25 & .038 & .944 & 25 & .179 \\
\hline
\end{tabular}

*This is a lower bound of the true significance.

${ }^{a}$ Lilliefors Significance Correction 
Pada Tabel 3 diketahui bahwa data telah diuji normalitasnya dengan dua metode, yaitu Kolmogorov-Smirnov dan Shapiro Wilk. Pengujian dengan Shapiro Wilk dilakukan karena jumlah sampel kurang dari 30. Jika dilihat dari hasil uji normalitas dengan metode Kolmogorov-Smirnov, diketahui bahwa nilai probabilitas pretest $(0,133)$ dan post-test $(0,179)$ keduanya lebih besar dari 0,05 sehingga Ho diterima atau dengan kata lain populasi dinyatakan berdistribusi normal. Pada kolom Shapiro-Wilk, jika dilihat dari nilai sig. dari kedua hasil uji pada Tabel 3 yang kesemuanya lebih besar dari 0,1 ; maka dapat disimpulkan bahwa data pada penelitian ini memang terdistribusi normal, sehingga hasil penelitian ini dapat digeneralisasikan pada populasi.

\section{B. Uji Paired Sample T-Test}

Setelah diketahui bahwa data yang diambil pada penelitian ini berdistribusi normal, selanjutnya perlu dilakukan uji Paired Sample T-Test untuk menguji perbedaan mean pada sampel yang sama. Pada penelitian ini, karena yang dibandingkan adalah nilai pretest dan post-test pada sampel yang sama, maka uji paired sample T-Test dilakukan. Hasil uji tersebut ditunjukkan pada Tabel 4.

Tabel 4. Hasil Uji Paired Sample T-Test

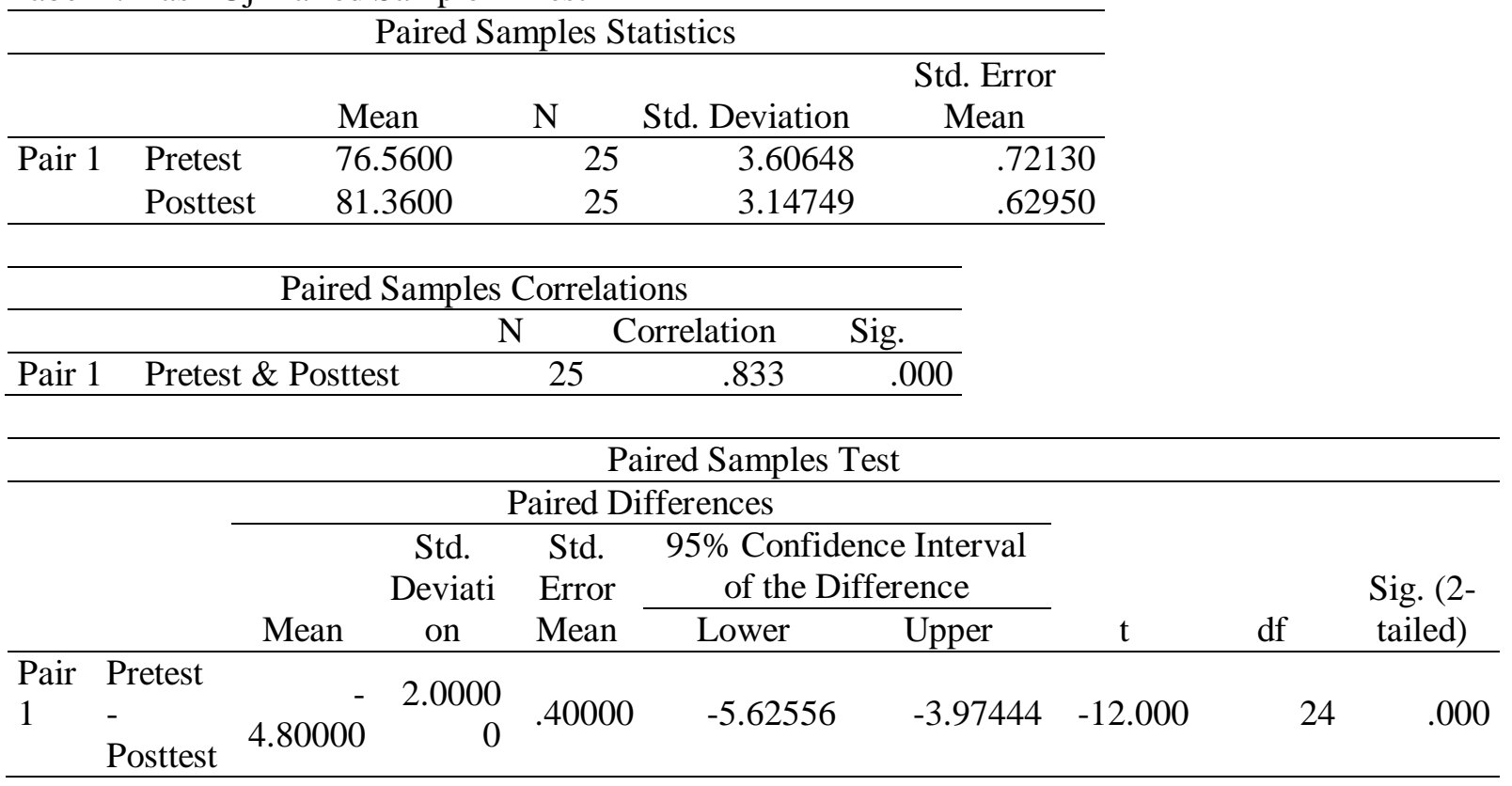

Dari hasil uji Paired Sample T-Test di Tabel 4 diketahui bahwa rerata kemampuan mahasiswa meningkat dari 76,5 menjadi 81 , 36 sedangkan simpangan bakunya turun dari 3 , 60648 menjadi 3,14749 dan rerata kesalahan baku juga turun dari 0, 7213 menjadi 0,6295. Dari hasil tersebut kemudian diketahui bahwa korelasi antara kemampuan siswa akan materi figurative language dengan treatment penggunaan teknik drama yang diberikan sebesar 0,00 atau lebih kecil dari 0,05 yang artinya hubungan keduanya signifikan. Dengan kata lain treatment penggunaan teknik drama telah berhasil secara signifikan menaikkan pemahaman siswa akan materi figurative language. Terlihat pula bahwa sumbangan penggunaan teknik drama pada peningkatan pemahaman mahasiswa akan materi figurative language adalah sebesar $0,833^{2}=0,69=69 \%$. Sedangkan $31 \%$ sisanya disebabkan oleh faktor lain. Sehingga korelasi antara penggunaan teknik drama dengan peningkatan kemampuan mahasiswa terhadap materi figurative language dikatakan kuat dan signifikan.

Selisih rerata dari pretest dan post-test sebesar $-4,8$. Nilai negative tersebut berarti telah terjadi kenaikan rerata nilai dari pretest ke post-test. Hasil uji t sebesar -12 dengan sig. (2-tailed) 0,0. Karena sig. $<0.05$ maka disimpulkan terdapat perbedaan pada taraf 5\% - Sehingga dapat dinyatakan bahwa penggunaan teknik drama secara signifikan mempengaruhi peningkatan kemampuan mahasiswa terhadap materi figurative language. 


\section{Uji Homogenitas Variansi}

Setelah distribusi sampel dinyatakan normal, maka perlu dilakukan uji homogenitas

Tabel 5. Hasil Uji Homogenitas Variansi

\begin{tabular}{lccc}
\hline \multicolumn{5}{c}{ Test of Homogeneity of Variances } \\
\hline var1 \\
\hline $\begin{array}{c}\text { Levene } \\
\text { Statistic }\end{array}$ & df1 & df2 & Sig. \\
\hline .006 & 1 & 48 & .938 \\
\hline
\end{tabular}

variansi dengan menggunakan One-Way ANOVA untuk mengetahui apakah hipotesis diterima atau ditolak.

\begin{tabular}{lccccc}
\hline \multicolumn{5}{c}{ ANOVA } \\
\hline var1 & \multicolumn{7}{c}{} \\
\hline & Sum of & & & & \\
& Squares & df & Mean Square & F & Sig. \\
\hline Between Groups & 288.000 & 1 & 288.000 & 25.138 & .000 \\
Within Groups & 549.920 & 48 & 11.457 & & \\
\hline Total & 837.920 & 49 & & & \\
\hline
\end{tabular}

Dari Tabel 5 tersebut diketahui bahwa dari hasil uji homogenitas variansi didapatkan nilai sig. sebesar $0,938>0,05$ sehingga dinyatakan kedua variansi identik. Selanjutnya dari hasil uji ANOVA diketahui nilai sig. sebesar $0,00<0,05$ sehingga dapat dinyatakan bahwa hipotesis diterima dan nul hipotesis ditolak. Dengan kata lain, hasil post-test berbeda secara signifikan dengan hasil pretest. Oleh sebab itu dapat disimpulkan bahwa penggunaan teknik drama dalam penyampaian materi figurative language telah berpengaruh secara signifikan terhadap peningkatan pemahaman siswa.

\section{Analisis Data Kualitatif}

Simpulan dari hasil kalkulasi statistik fase pertama penelitian menjadi dasar penyusunan panduan pertanyaan untuk grup diskusi terfokus. peneliti membagi mahasiswa-mahasiswa dalam beberapa kelompok kecil yang terdiri dari 5-6 orang. Secara bergiliran, peneliti akan memandu diskusi terfokus di setiap grup. Diskusi sengaja dilakukan di dalam grup agar mahasiswa merasa lebih nyaman dan tidak segan mengemukakan pendapatnya. Setiap diskusi direkam dengan kamera video, alat perekam suara, dan catatan lapangan. Data-data ini kemudian dirumuskan dalam beberapa tema yang menjelaskan persepsi mahasiswa akan penggunaan metode drama dalam pembelajaran topik Figurative Language di kelas Speaking. Dari hasil diskusi grup menunjukkan bahwa para mahasiswa mempunyai persepsi dan sikap yang positif terhadap penggunaan drama project untuk pembelajaran figurative language, mereka menyatakan bahwa belajar makna kiasan akan lebih mudah jika langsung digunakan dalam kalimat percakapan yang ada dalam naskah drama ( script) yang mereka buat dan langsung dipraktekkan dalam dialog-dialog drama.

\section{SIMPULAN}

Dari analisa data baik secara kuantitatif maupun kualitatif dapat disimpulkan bahwa penggunaan teknik drama dalam pembelajaran figurative language telah berpengaruh secara signifikan terhadap peningkatan pemahaman siswa serta dapat meningkatkan kepercayaan diri mahasiswa untuk berbicara sehingga secara tidak langsung juga dapat meningkatkan kemampuan speaking para mahasiswa Diharapkan untuk penelitian-penelitian selanjutnya untuk dapat memperluas lingkup pemilihan jenis figurative language yang 
diajarkan karena didalam penelitian ini hanya terbatas pada enam jenis figurative language saja.

\section{DAFTAR RUJUKAN}

Cresswell, J.W. 2009. Research Design:

Qualitative, Quantitative, and Mixed

Methods Approaches. Thousand Oaks,

California: SAGE Publications, Inc.

Latief, M.A. 2012. Research Methods on Language Learning: An Introduction. Malang: UM Press.

Retnayanthi, P.A. 2013.The analysis of figurative language in Adele's song lyrics. Educational journal 1(1).14-19.

Utami. 2012. Profil masalah-masalah pembelajaran pada mata kuliah poetry. Jurnal pendidikan dan Pengajaran. 45(3). 210-219. 